\title{
Review
}

\section{Corporate Concentration and Technological Change in the Global Seed Industry}

\author{
Sylvie Bonny \\ Economie Publique, AgroParisTech, INRA, Université Paris-Saclay, 78850 Thiverval-Grignon, France; \\ sylvie.bonny@inra.fr
}

Received: 12 July 2017; Accepted: 6 September 2017; Published: 14 September 2017

\begin{abstract}
In the past three decades, the seed sector has experienced, and is now again experiencing, corporate concentration trends. The fallout of this consolidation is the subject of numerous concerns. However, the seed sector is rather poorly understood. Thus, it is useful to understand it better and to investigate the potential impact on the agri-food chain of the trend toward increased corporate concentration. The first part of this paper presents the main characteristics of the global seed sector, its stakeholders, and its size in the agri-food chain. Next, the corporate consolidation trends of the seed industry over the past two years are examined. The technological evolution of the seed sector is also briefly presented. In the last part of this paper, the fallout of recent mergers and acquisitions in the seed industry are analyzed. Opposing views are expressed on the impact of these mergers and acquisitions in the agri-food chain: while certain stakeholders worry about the risk of food power by the biggest companies, some others expect useful innovations.
\end{abstract}

Keywords: seed; seed industry; seed company; agri-food chain; corporate concentration; consolidation; biotechnology; plant breeding; controversy; agriculture

\section{Introduction}

Seeds play a significant role in the sustainability of the agri-food system, as they are at the very beginning of the food chain, and thus constitute its base and foundation. Hence, the consolidation of the seed sector in recent decades, and particularly in the past few years, has become a topic of concern. The 2015-2016 wave of mergers and acquisitions has brought about many worries since concentration among the five largest groups is still growing. Indeed, certain stakeholders and concerned citizens are worried about the consequences of this corporate consolidation for the diversity of available seeds and their adaptability to the variety of farmers, agroeconomic conditions, and crops, as well as about the risks of creating an oligopoly. They are also concerned about the control over the food system gained by the major players in the seed sector [1-4]. In addition, over the past decades, trends in the evolution of the seed sector have been raising concerns for two main reasons: (i) corporate consolidation resulting in a concentration of resources and of plant breeding and seed supply into a limited number of hands and places, hence the fear of increased farmer and food dependency on a few big companies; and (ii) the development of biotechnology and new plant breeding techniques with the controversies accompanying these methods. However, stakeholders of the seed industry and other actors point to major progress resulting from advances in the seed sector, such as increased yields allowing for land sparing, easier work for farmers, valuable characteristics introduced in improved seeds, as well as increased attention devoted to the environment, and to demands by the food processing industry and consumers. These voices also underline the need for consolidation in the seed industry to better cope with the agricultural and food challenges of the coming decades.

Therefore, it is useful to better analyze the seed sector, its consolidation trends in the past few years, and their repercussions. There have been many comments on this topic in the media, as well 
as letters and hearings, but few scientific papers that mainly deal with the issue in the case of North America [5-12]. This analysis is particularly essential given that the seed sector is a major player and a major actor of sustainability when we consider the many agricultural, food and climate issues today and in the future. Indeed, plant breeding, in conjunction with crop practices and the various uses of production, influences the type and diversity of products obtained (food, feed, bioresources, fibers, etc.), the characteristics of production, their environmental impact, and food security issues, including some nutritional aspects [13]. In addition, the techno-economic and institutional characteristics of the seed sector can affect the accessibility of seeds as well as their prices and ways of using them.

As early as the end of the 1980s, during the first field trials of transgenic plants, a controversy arose, and has not stopped for 30 years. On the contrary, it has grown more and more intense over time. Indeed, the use of genetic engineering in plant breeding has led to many debates on the interests and risks of GMOs [14]. This has drawn attention to the techniques used in plant breeding and to the seed industry in general, particularly its largest companies. Non-governmental organizations (NGOs) and certain citizens and activists have become very critical of the seed industry, notably of multinational seed companies. They often denounce increasing corporate consolidation that leads to a risk of food dependence on some firms [1,4]. These criticisms have been widely circulated by the media and the Internet. Hence, multinational seed companies are often criticized in NGO papers and in the media, but this representation varies by country. For some stakeholders, particularly in Europe, these companies have become very powerful organizations that have deprived and are depriving farmers of their know-how and seed resources, and who have a growing power over agriculture and food through plant breeding and seed production. The importance of the seed multinational companies and the growth of their market shares are frequently highlighted. On the contrary, other players, particularly in the USA, see the seed sector-particularly the biotechnological applications designed and implemented by the biggest firms-as an essential means of quickly transferring new, interesting traits to plants. They believe that these technologies could better address the agricultural, food, and climate challenges of the coming decades, and additionally that the contribution of these companies to the economy of the nation is essential. Thus, the issues of technological change and structural change in the seed industry, as well as their perception and acceptance, are linked.

The main goal of this paper is to analyze the ongoing consolidation wave in the seed industry at a global level, its possible impact, the issues at stake, the concerns expressed by many people, and the benefits claimed by some stakeholders. The first two sections give an overview of the seed sector, its various stakeholders, the issues at stake, the effects of technological change, and the concentration trends of the past few decades, as well as data on the global seed market, the sales of the main companies, and the structure of the seed industry. The last section deals with the potential impact of corporate consolidation in the seed industry. The paper first studies the seed sector in order to provide more accurate and quantified elements for assessment. This can contribute to a better analysis of the many issues linked to seeds and of the ongoing consolidation, and thus to a better understanding of related controversies and polemics. Indeed, the world of seeds remains poorly known outside the circle of specialists in the field. In a certain way, the controversy has worsened this lack of understanding as a result of claims that are too Manichean, simplistic, or partial. While many articles discuss this sector, notably targeting GMOs, detailed analyses and precise assessments remain quite rare outside the specific domain of market studies carried out by market research companies, which primarily focus only on market forecasts. Therefore, the aim of this paper is to provide a better understanding as well as elements for evaluation of the role and weight of the seed companies among the many stakeholders involved in the way that agriculture, food, and the bioeconomy evolve. There are many stakeholders in the agri-food chain [15]. In addition, in each of its sectors, there are several operators. For example, in the seed sector itself, there are many actors, as indicated below in the discussion of its heterogeneity. In summary, the agri-food chain includes numerous operators that can be listed as follows: trait providers, seed companies, seed distributors, farmers, agricultural commodity buyers (cooperatives or private firms), wholesale traders, exporters and importers, food processors, central purchasing 
agencies, wholesalers, food retailers, and consumers. In addition, because of the importance of food, many other stakeholders intervene very actively in the debate, such as NGOs, journalists, scientists, and concerned citizens.

The paper is structured in three parts: (1) the global seed market in the food chain, its stakeholders, size, and heterogeneity; (2) corporate concentration trends and technological evolution in the seed industry; and (3) impact of corporate consolidation on the seed industry. The first part deals with the seed sector from an economic point of view on a global scale, discussing its importance in the agri-food chain. The second part analyzes the concentration trend and the technological evolution of the sector during the past few decades and the past few years in particular. Finally, the third part aims to examine the effects of technological and structural changes in the seed industry, and the issues raised by increased concentration.

This article draws on a long and complex process of search, retrieval, compilation, collecting, comparison, and analysis of specific data, retrievable statistics, and detailed information on the seed sector. It also draws on the various points of view expressed by the involved stakeholders (farmers, NGOS, companies, people speaking in parliamentary hearings, scientists). These data come from a great number of sources: papers by experts; seed sector economists or NGOs; company reports for their investors or for market regulatory authorities; assessments, presentations and communications of seed professionals at conferences; and the scientific literature and monitoring of this sector. Analysis of the seed sector is a particularly difficult task given the extent of partial or biased analyses, as well as a lack of data on certain aspects. Moreover, the economic data are heterogeneous and sometimes non-concordant. This is notably the case for the global commercial seed market, for which evaluations can vary by twice as much (see below). Regarding global sales of the main seed companies, several factors can also lead to discrepancies in their assessments: mismatches between the exercise dates adopted by each firm, which leads to differences in the exchange rate of currencies used; as well as segment itemization, given that company results do not always provide a detailed breakdown of their product sales or R\&D expenditures. Thus, some rather debatable data or statements, sometimes approximate yet frequently quoted or taken up, acquire a kind of validity.

\section{The Global Seed Market: Stakeholders, Size, and Heterogeneity}

In this section the seed industry will be described per its situation in 2015-2017, without considering the consequences of the 2015-2016 mergers and acquisitions. Indeed, this last consolidation wave was not yet completely achieved by the end of June 2017, since a certain number of authorizations by antitrust agencies were still pending. In addition, this picture facilitates a better understanding of the recent wave of consolidation, the outcome of which is analyzed further below.

\subsection{The Sector's Economic Weight in the Agri-Food Chain}

Seed companies are often regarded as very large firms and powerful players in the agri-food chain. In particular, the major firms are often viewed as giant companies with considerable power. However, if one considers the size of the largest company (Figure 1) or of the ten largest ones (Figure 2) (based on total sales) of the different sectors in the agri-food chain, the one of the seed sector is the smallest within the food chain. Indeed, in the agri-food chain, the most important sectors and actors by far are food processing and large-scale distribution. It is interesting to compare the total global value of purchased seeds to the total value of food globally. Although it is difficult to estimate the latter, it appears that the total value of purchased seeds (around 48.5 billion USD) roughly represents a little less than $1 \%$ of the total value of purchased or self-produced food globally (approximately 5000 to 6000 billion USD). At the farm level, a similar evaluation can be made if we compare the average value of purchased seeds per farm to the value of the resulting agricultural production: 100 USD or euros of the latter required an average of 4.9 USD in the USA (on average for all farms in 2012) and 3.5 euros of purchased seeds in France in 2014 (for medium to large farms) [16,17]. 


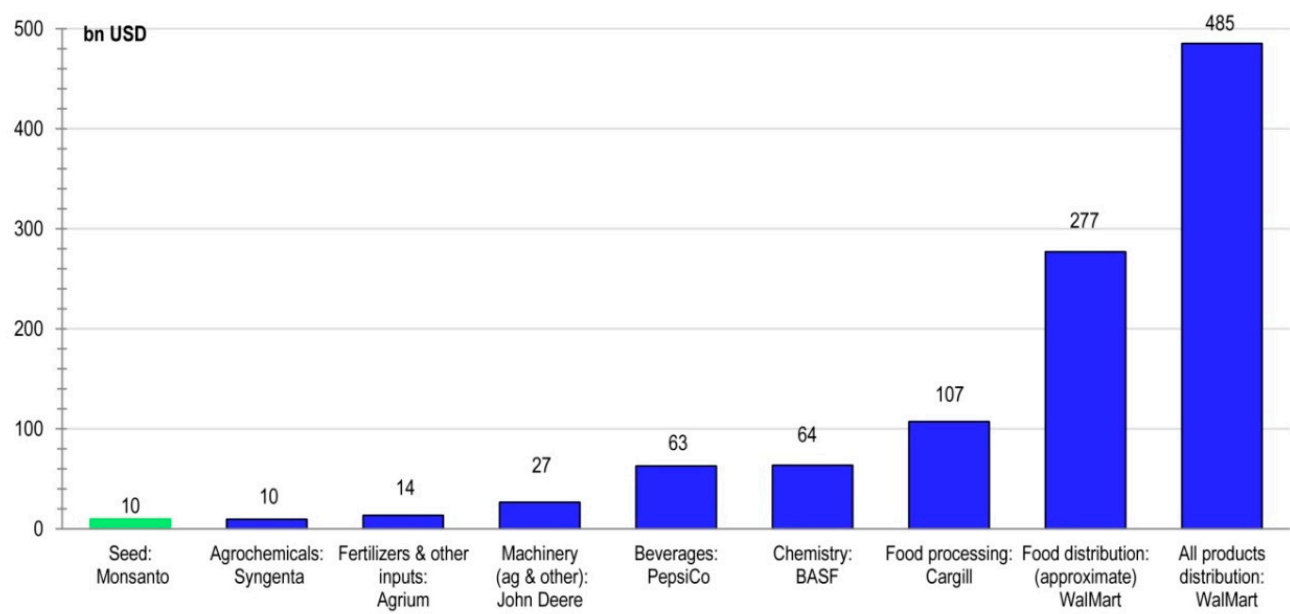

Figure 1. Size of the largest company of each sector in the agri-food chain and in chemicals globally in 2016 (sales in billion USD) (established from Forbes [18] and financial reports by companies). The name of the major group is indicated below each sector's name.

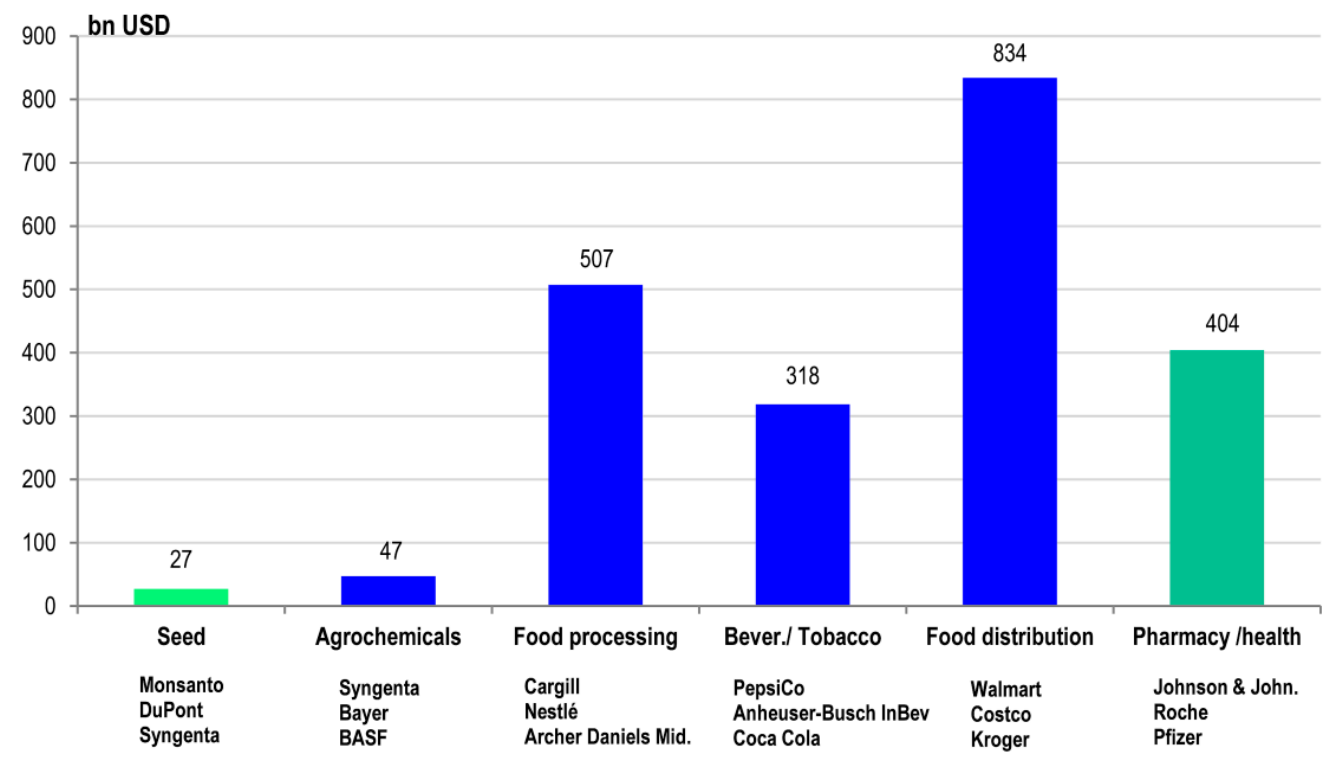

Figure 2. Size of the top 10 companies in each of the different sectors in the global agri-food chain and in pharmacy (including consumer health products) globally in 2016 (sales in billion USD) (established from Forbes [18] and financial reports by companies). The names of the three major groups are indicated below each sector's name.

Thus, seeds have a low economic weight in the agri-food chain, because the added value is much higher at the end of the agri-food chain than at its beginning. However, the importance of seeds is considerable if we take into account their role and influence on the success of crops and on food security due to their agronomic, techno-economic, environmental, and nutritional impact.

The total size of the seed market is not well known due to the difficulty of assessing the value of seeds saved by farmers and the total value of the commercial seed market. The latter was approximately 48.5 billion USD in 2015, according to some experts [19,20]. However, there are great discrepancies between the various assessments made by different market study companies (Table 1). Several of these companies publish reports on the global commercial seed market as a whole, as well as broken down by company, region, kind of crops, and type of seeds (conventional, hybrid, and GM). These reports on the global seed market show that, despite these differences, market study companies generally forecast 
rapid growth of this market in the next few years, with a compound annual growth rate that varies from $6.8 \%$ to $13.3 \%$ (Table 1 ).

Table 1. Several assessments of the global commercial seed market in 2015-2016 and forecasts for the next few years from reports by some market study companies (ranked by year of forecast).

\begin{tabular}{|c|c|c|c|c|c|c|}
\hline $\begin{array}{l}\text { Market Study Company } \\
\text { (Headquarters Location) }\end{array}$ & $\begin{array}{c}\text { Year of } \\
\text { Assessment } \\
\mathbf{n}\end{array}$ & $\begin{array}{l}\text { Global Seed Market in } \\
\text { n (Billion USD) }\end{array}$ & Year & $\begin{array}{c}\text { Year of } \\
\text { Forecast } p\end{array}$ & $\begin{array}{c}\text { Global Seed } \\
\text { Market in Year } \\
\text { p (Billion USD) }\end{array}$ & $\begin{array}{l}\text { CAGR (Compound } \\
\text { Annual Growth } \\
\text { Rate) }(\% \text { and } \\
\text { Period) }\end{array}$ \\
\hline $\begin{array}{l}\text { Phillips McDougall (UK) (for } \\
2 / 3 \text { of the main global crops, } \\
\text { not all) }\end{array}$ & 2015 & $\begin{array}{l}\text { GM seeds: } \\
\text { Conventional seeds: } \\
\text { Total: }\end{array}$ & $\begin{array}{l}17.8 \\
17.4 \\
35.2 \\
\end{array}$ & & & \\
\hline $\begin{array}{l}\text { Transparency Market Research } \\
\text { (India) }\end{array}$ & 2011 & 34.5 & & 2018 & 53.3 & 9.9 (6 years) \\
\hline Orbis Research (USA, India) & 2013 & 49.23 & & 2019 & 82.49 & 9.1 (6 years) \\
\hline Infinium (India) & 2016 & 53.5 & & 2021 & 96.8 & 12.6 (5 years) \\
\hline Market Data Forecast (India) & 2016 & 64.1 & & 2021 & 99.53 & 9.2 (5 years) \\
\hline Global Market Firm (USA) & 2014 & 23.65 & & 2022 & 55.3 & 11.2 (8 years) \\
\hline $\begin{array}{l}\text { Stratistics Market Research } \\
\text { Cons (USA) }\end{array}$ & 2015 & 26.2 & & 2022 & 55.3 & 11.2 (7 years) \\
\hline Mordor intelligence (India) & 2017 & $56.3(50$ in 2014$)$ & & 2022 & 78.2 & 6.8 (5 years) \\
\hline MarketsandMarkets (India) & 2015 & 58.5 & & 2022 & 113.3 & 9.9 (from 2017) \\
\hline Strategyr (USA) & & & & 2022 & 130 & \\
\hline IMARC Group (India) & 2016 & 58 & & 2022 & 86 & $6.8(2017-2022)$ \\
\hline Accuracy Research LLP (India) & 2015 & 58.7 & & 2025 & 204.5 & 13.3 (10 years) \\
\hline
\end{tabular}

Discrepancies in global commercial seed sales are important to consider, because assessments of the level of market concentration require an accurate evaluation of the global market, as well as accurate data on each company's sales. As mentioned above, these data can vary depending on the source. Thus, when the level of consolidation is discussed, it is necessary to examine which data are taken into account. In particular, the assessment of the global seed market by the consultancy company Phillips McDougall is frequently cited, as this company is renowned. However, its reports take into account only seeds of two-thirds of the main global crops (in terms of total cultivated area), i.e., approximately only three quarters of global commercial seed sales, since crops have different seed values [21] (p. 12). Therefore, its estimates are lower than the real total value, yet are often erroneously considered to reflect the value of the total commercial seed market. Hence, the value of the global commercial seed market is often underestimated. In addition, the value of each company's sales depends on the currency exchange rate used. Some sources use exchange rates of the civil year for all companies, while others use exchange rates of the given exercise date of each company. Hence, there may be differences in the amounts cited.

\subsection{A Heterogeneous Sector}

The seed sector is very heterogeneous in many respects, such as the kinds of seeds, and the origin and size of seed suppliers. Analysis of the ongoing corporate consolidation of the seed industry requires a good understanding of its structure, its different stakeholders, and its internal heterogeneity to avoid a focus on the biggest companies that fails to account for other stakeholders and the diversity of situations among countries and crops. In addition, this heterogeneity plays a great economic role, and thus influences consolidation. Certain aspects of this heterogeneity that prove useful in understanding the issues at stake in the seed sector are presented below: the diversity of seed types, of companies, of companies' main activities, of their involvement in agricultural inputs, and of seed values depending on crops. The data come from various sources: scientific and professional literature 
on the seed sector, company reports, analyses by market study companies, presentations by the International Seed Federation, reports by ISAAA (the International Service for the Acquisition of Agri-biotech Applications), and a monitoring of the seed sector.

\subsubsection{Different Kinds of Seeds}

Globally, but also in many individual countries, different kinds of seeds can be distinguished among those used by farmers:

- “Conventional" seeds are supplied by approximately 7500 companies of different sizes from around the world.

-GM seeds are usually created by big companies. However, smaller companies can also sell GM crops through license agreements on genetic traits.

-Farmers' seed systems result from the breeding efforts of farmers in their fields to obtain seeds that they expect to be better suited to their soil, practices, and needs. While these have become less important in industrialized countries because of the development of hybrid seeds for some crops, they can constitute a substantial part of the seeds sown in less-developed countries.

-Farm saved seeds are sown and harvested from conventional seeds purchased in the previous year. Seeds from a small fraction of this harvest are sown the next season after sorting and cleaning. It is essential to differentiate these seeds from the farmers' seed systems mentioned above, since these saved seeds are a kind of "copy" of purchased seeds rather than newly-bred ones.

-Seeds from public research are rarely sold as end-user seeds to farmers since public research generally works upstream in plant breeding.

The relative importance of these different kinds of seeds varies greatly from country to country and from one kind of crop to another. This fact results in a considerable variety of situations depending on country and crop. These different kinds of seeds as regards their different methods of breeding and creation are important to keep in mind, since many statements regarding the seed sector do not sufficiently consider its internal diversity or the distinction between "farm saved seeds" and "farmers' seed systems."

\subsubsection{Different Kinds of Companies}

The various seed companies are very diverse in size as well as in the extent of their other activities when seeds are only a part of a multisector company. One can roughly distinguish among the 7500 seed companies in the world as follows:

-A handful of companies come from the chemical industry, and are by far among the largest seed companies. These companies have an unequal involvement in plant breeding and seed activities (Figure 3).

-Many SMEs (small and medium enterprises) have been able to remain in place despite numerous acquisitions by some of the larger companies in the last few decades.

-Many very small enterprises have been able to remain in place, as they are more specialized in rather local and specific crops, and thus less attractive for the big companies to acquire, who have mainly invested in major crops such as corn, soybean, and some vegetables. 


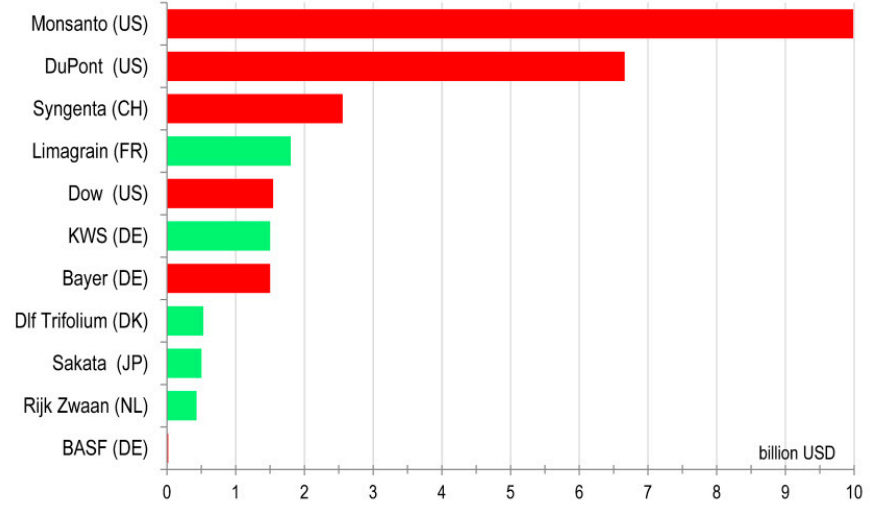

Figure 3. The twelve main global seed companies ranked by their global seed sales in billion USD in 2016. NB The seed companies in red come from the chemical sector, and those in green come from the agricultural and seed sector. Although its seed sales are insignificant, BASF is included because of its R\&D investments in plant breeding and seeds, and because it belongs to the "The Big Six" group. For Limagrain and KWS, sales figures include those of AgReliant, their 50/50 joint venture.

\subsubsection{Different Kinds of Company Origin}

Seed companies are also heterogeneous in origin. While the small and medium enterprises (SMEs) have an agricultural origin, the leading companies (except Limagrain and KWS) come from the chemical and agrochemical industry. Among the ten largest seed companies, half are of chemical origin: Monsanto (USA), DuPont (USA), Syngenta (Switzerland), Dow (USA), and Bayer (Germany). Indeed, in the 1990s, several chemical companies involved in pesticides developed a seed segment and/or acquired seed enterprises. One reason for these investments in the seed sector was expectations for better returns, particularly because the cost of introducing a new agrochemical ingredient on the market was on the rise at the time, and is still increasing in real prices (Figure 4). In the early 2010s, this cost remained much higher than the one involved in launching a new biotech trait on the market [22,23]. Other major reasons were the onset of GMOs, the prospects of biotech applications, and a growing interest in life processes. Some put forward the possibility of a new agricultural revolution based on enhanced information, data processing, and new information technologies on the one hand, and on a better valorization of life processes on the other. This new revolution could progressively replace the second agricultural revolution, mainly based on the use of non-renewable resources and chemicals. This prospect has gained renewed interest, with the notion of bioeconomy frequently put forth by some organizations.

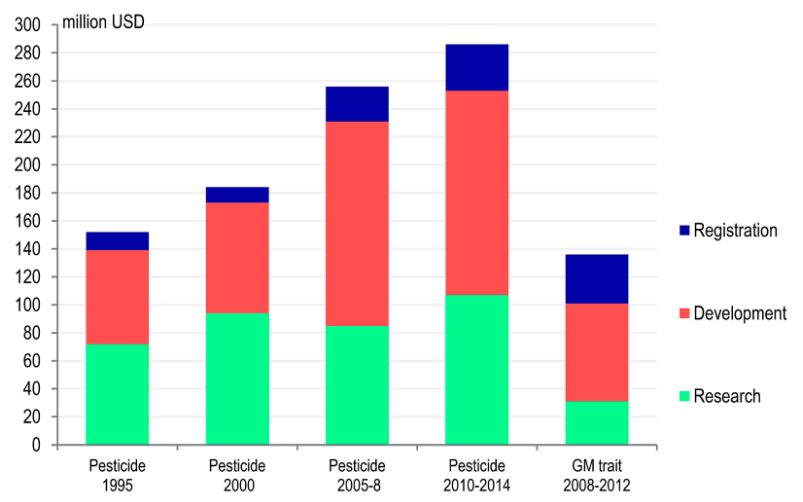

Figure 4. Cost of discovery, development and registration for a new agrochemical product and a new GM seed trait in 1995, 2000, 2005-2008 and 2010-2014 (million USD) (from [22,23]). 
The five agrochemical groups mentioned above, plus BASF (Germany) (who invests in the seed sector without already selling seeds), are often called "The Big Six" because their sales of both pesticides and seeds rank them at the top level for these agricultural inputs (Figure 5). Because of their chemical origin, these companies have often brought certain economic behaviors into the seed sector, such as the implementation, broadening, and strengthening of intellectual property rights, which are common in the chemical industry, but were previously rather rare in the seed sector. This development, however, is also the result of several contributing factors in the last few decades, such as public policies and regulatory regimes [24,25].

\subsubsection{Different Kinds of Company Profiles}

The largest seed companies are also heterogeneous in the relative importance of seed and pesticide sales to their total agricultural segment. Monsanto and DuPont have a high share of seeds in their total agricultural sales, while Syngenta, Bayer, Dow, and BASF mainly sell pesticides (Figure 5). In addition, some of "The Big Six" are highly involved in various sectors of the chemical industry other than the agricultural input sector, particularly in the pharmacy and general chemistry sectors (Figure 6). Thus, the biggest seed companies have very different profiles, depending on the importance of the seed segment among their total activities. Monsanto and the pure seed companies are the only companies whose primary work is the seed sector, while their competitors, particularly BASF, Bayer, Dow, and DuPont, have large activities and assets in pharmacy and/or chemistry, which give them much more strength. Limagrain is also active in food processing, but this activity is much smaller than its seed activities, which represent more than $79 \%$ of its sales.

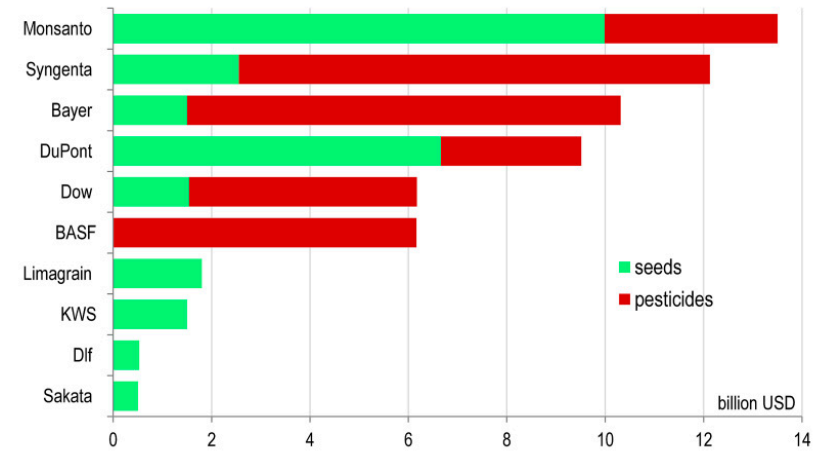

Figure 5. Sales of seeds and pesticides by "The Big Six" and the other main seed companies in 2016 (in billion USD).

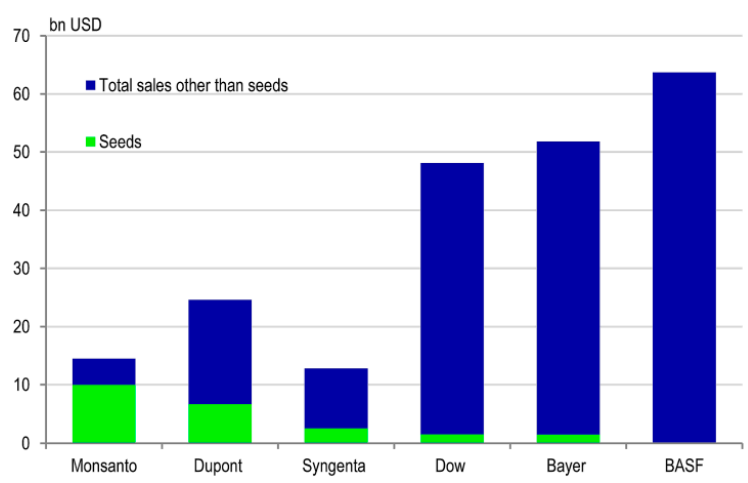

Figure 6. Seed sales and total sales by "The Big Six" in 2016 (in billion USD). 


\subsubsection{Different Kinds of Seed Values}

Seeds are also very heterogeneous in value depending on the crop. Sugar beets, vegetables, corn, and soybean seeds are expensive per hectare, while the seed cost of cereals other than corn is considerably lower. Thus, some crops, such as corn and soybeans, represent a significant portion of the global seed market that is much greater than their acreage share in the total cultivated area. For example, in 2015 , corn represented more than $30 \%$ of the total commercial seed market, while its global acreage was only about $11.5 \%$ of cultivated area, and soybeans represented almost $17 \%$ of the commercial seed market, while its acreage was only about $7 \%$. This relative value of crop seeds explains why big seed companies concentrate their activities on certain crops more than on others.

In addition to this internal heterogeneity, the seed industry involves different kinds of sub-sectors. Only the plant breeding sector and related companies are considered in this paper. However, the seed industry also involves farmers who multiply early generations of newly bred varieties; companies that clean, package and market the final seeds; and seed retail enterprises that sell seeds to end users.

\section{Corporate Concentration Trends and Technological Evolution in the Seed Industry}

\subsection{Concentration Trends from 1985 to 2015}

Corporate consolidation in the seed sector has grown progressively over the last decades (Figure 7), with a more rapid pace in the 2000s. Such consolidation was realized through many mergers and acquisitions by large companies, notably Monsanto, Syngenta, and DuPont [8,26-29]. Over the 1985-2015 period, the top five companies considerably increased their market share, while intermediate seed companies had a stagnant market share, and a certain number of SMEs disappeared or were absorbed. The new wave of mergers and acquisitions among "The Big Six" in 2015-2016 will increase the market share of the leading companies.

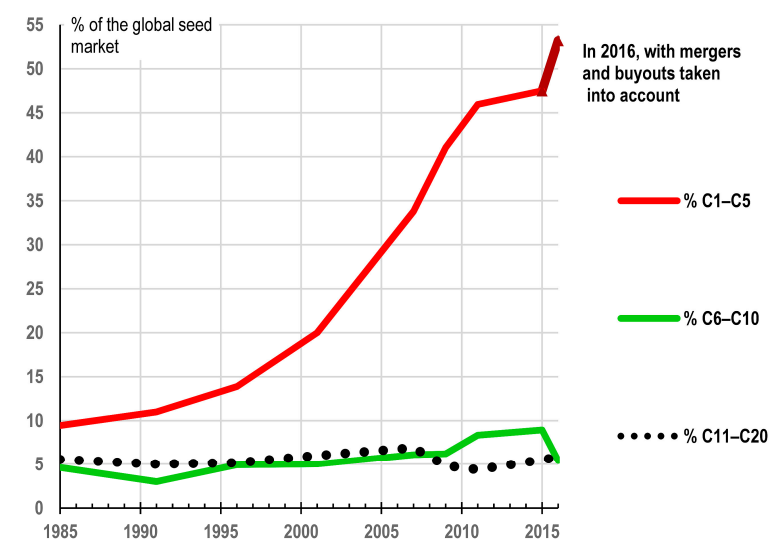

Figure 7. Concentration trends in the seed industry, 1985-2016 (y-axis: percent of the global commercial seed market). C1-C5 represent the market share made by the first five companies; $\mathrm{C} 6-\mathrm{C} 10$ reflect the same by companies ranked 6th to 10th; and C11-C20 the market share by companies ranked 11th to 20th. These assessments are approximate because of difficulties in evaluating the global commercial seed market as well as each company sales given their heterogeneous exercise dates and the variability of currency exchange rates.

Another major factor of concentration trends in the last 20 years has been the growth of GM seeds (Figure 8) [30]. Indeed, these seeds are more expensive than conventional ones because of technology fees, and are mainly sold by the largest companies [31]. This has increased the market share of the latter. 


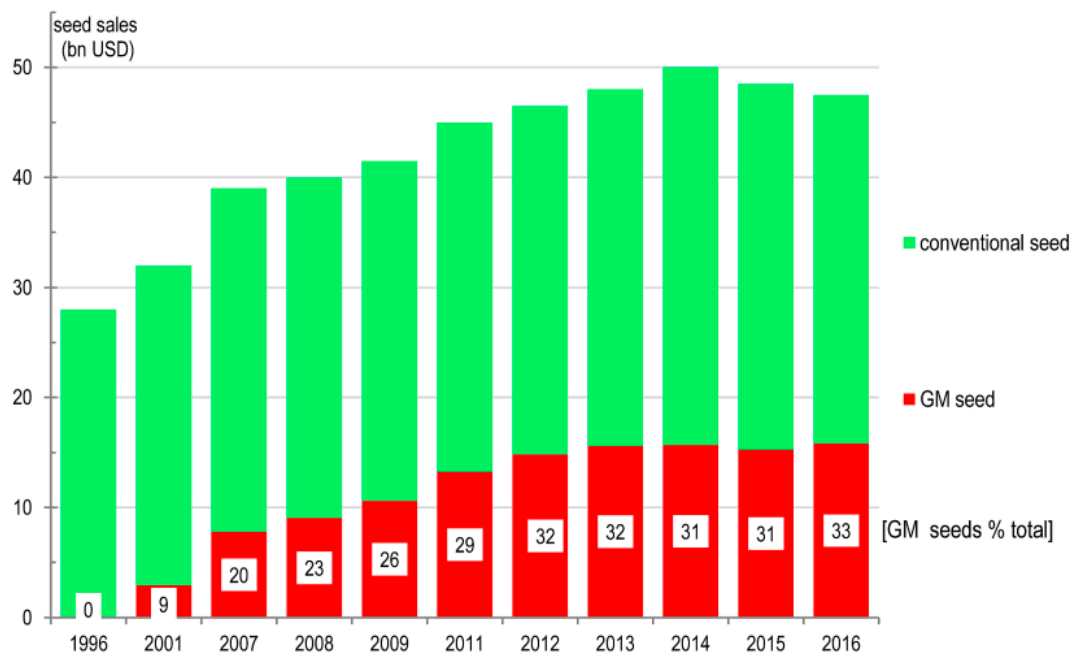

Figure 8. The growing share of the GM seeds in the global commercial seed market. Source: author's calculation from ISAAA (International Service for the Acquisition of Agri-biotech Applications) [30] data on the GM seed market and rough assessments of the global seed market.

\subsection{Wave of Mergers and Acquisitions among "The Big Six" in 2015-2016}

Corporate concentration and the internationalization of companies can be observed in many sectors of the economy. For example, during the last decade, from 2007 to 2016, there were on average more than 44,000 mergers and acquisitions per year in all industries worldwide [32]. This trend results from various factors, such as the search for economies of scale and economies of scope, the pursuit of comparative advantages, the search for a strong or dominant commercial position in the market, and the imperative for profitability in the financial markets, as well as strategies adopted for positioning themselves and for asset acquisition in businesses considered particularly promising. In addition, mergers and buyouts allow several activities and research facets to act synergistically and to create additional capabilities. Growth in size also gives companies greater R\&D capabilities, either internally or through the acquisition of highly innovative enterprises and start-ups. These R\&D activities, in turn, allow advances that favor a strengthening of position for large firms. Furthermore, consolidation can give access to new resources, such as genetic resources in plant breeding, as well as to new markets or to activities in which the acquired company was already active. Concentration trends are also often linked to technological and regulatory developments that lead to an increase in the costs of placing new products on the market. In many sectors, this increase reinforces the predominance of the big firms, which are more capable of coping with it.

As regards the big agrochemical and seed companies, why did a new wave of mergers and acquisitions take place from 2015 to 2016? In addition to all the general elements mentioned above, several aspects played a specific role. In 2015-2016, seed and agrochemical companies encountered economic difficulties: the decrease in agricultural prices and revenues and certain weather conditions led to a downturn in seed and pesticide sales by ag-input companies. Global sales of pesticides fell by $9 \%$ between 2014 and 2015, and so did seed sales, but at a lower rate. This decrease continued in 2016 for pesticides, but attenuated $(-2.7 \%)$. The pesticide industry was also increasingly marked by the tightening of regulation in many countries. As a good return on shares is necessary for these companies that highly depend on financial markets and on their shareholders, new mergers appeared as a good option. In addition, low interest rates during 2016 allowed companies such as Bayer to have a financing cost that was not too heavy to bear. Furthermore, all companies upstream in the agri-food chain predict that, due to population growth and the resulting decrease of cultivated area per person, more agricultural inputs will be needed in the new few decades, notably enhanced seeds. This trend is accentuated by climate change, the spreading of diseases and pesticide resistance, and certain aspects 
of consumer demand. Thus, the agricultural sector's future is considered bright. However, these companies should beware of seed and other input prices, particularly when agricultural revenues are low, as was the case in the past few years.

How does the ongoing wave of consolidation compare to the previous waves, particularly the important wave of the 1990s, which led to the creation of "The Big Six"? Schenkelaars et al. [33], who have studied the drivers of consolidation in the seed industry in the past few decades until 2010, pointed out that concentration results from multiple factors, notably the dynamic interplay between business strategies, scientific breakthroughs, and government policies. These drivers also played a considerable role in the 2015-2016 concentration wave. R\&D costs are, notably, a critical factor in the seed industry strategy, as they can lead to strategic alliances, joint ventures, and mergers and acquisitions to reduce their weight and to obtain adequate returns on invested capital. Therefore, companies will be highly affected if their sales decrease as in 2015-2016; this can lead to concentration trends. Could the rather depressed agricultural prices in the 1990s have also favored the consolidation wave [34]? This factor certainly played a role, however, only in interplay with the other drivers mentioned above. In addition, each period has its specificities. In the 2015-2016 concentration wave, it is important to take into account recent facts that were barely present in the 1990s, but that now influence the strategies employed by the seed industries, such as the prospects of decline of cultivated area per capita, the impact of climate change, the tightening regulation of new ag-input authorizations, and the rapid development of digital farming. These factors shape a new context and a new reality, with opportunities and pressures that may favor new kinds of company relationships, alliances, agreements, or buyouts.

All "The Big Six" except BASF were involved in this wave of mergers and buyouts:

(1) In May 2015, Monsanto sought to buy Syngenta, a Swiss company. However, the latter refused, considering that the price offered was too low.

(2) In December 2015, Dow and DuPont-Pioneer merged, and formed a new group, DowDupont.

(3) In February 2016, ChemChina (China National Chemical Corporation), a chemical conglomerate of the Chinese state, acquired Syngenta for 43 billion USD.

(4) Bayer, the large German chemical group involved in pharmacy, over-the-counter health products, animal health, seed, agrochemicals, and materials, had been considering the acquisition of Monsanto since May 2016. The acquisition was agreed upon at 66 billion USD in September 2016.

Some of the above transactions are still underway, since the authorization processes are not yet concluded. Indeed, mergers and acquisitions must be authorized by antitrust authorities, who seek to prevent the substantial reduction of competition in a market, as well as counter-competitive situations that lead to increased prices, lack of choice, or oligopolies. For example, regarding the acquisition of Monsanto by Bayer, approval is needed by antitrust authorities in 30 countries [35].

By the end of June 2017, some important approvals had already been obtained.

ChemChina completed its takeover of Syngenta in late June. Regulators required that ChemChina divest several pesticides so that the new entity would not hold too high a market share for a number of pesticides with too few other competitors.

Dow and DuPont-Pioneer won EU approval for their $\$ 130$ billion merger at the end of March 2017. The approval is contingent on major divestitures from the DuPont pesticide business to preserve competition in the market: it must sell some of its pesticide assets, as well as cease some of its related $R \& D$ activities. In addition, within two years of the completion of the mergers, the combined entity, dubbed DowDuPont, must split into three independent companies, focused on agriculture, material science, and specialty products.

However, at the end of June 2017, Monsanto's acquisition by Bayer had yet to receive approval from several regulators. In May 2017, Bayer agreed to sell its glufosinate herbicide and LibertyLink branded seeds, which are glufosinate-tolerant and compete with Monsanto's glyphosate-tolerant seeds. 
The very first picture of these three mergers and takeovers can be established as regards the global sales of the newly formed entities: Bayer + Monsanto, ChemChina + Syngenta, and Dow + Dupont (Figure 9). This illustration adds the seed and crop protection sales of the groups above that are in the process of a merger or a buyout. However, this first assessment does not take into account some requested divestments, nor the latest values of seed and pesticide sales for each company. The impact on the level of concentration is analyzed below.

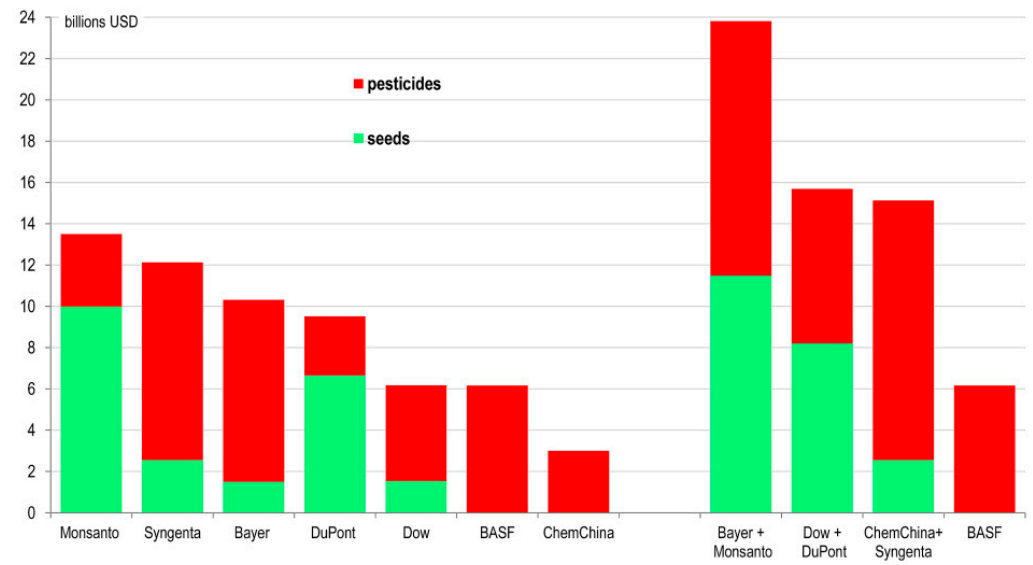

(1) Previous situation (2002-2014) with six large groups, "The Big Six": Monsanto, Syngenta, DuPont, Bayer, Dow, and BASF.
(2) Possible situation in 2017, following the 20152016 concentrations leading to four main groups, "The Big Four": Bayer + Monsanto, DowDupont, Syngenta + ChemChina, and BASF.

Figure 9. A preliminary view of the outcome of the 2015-2016 wave of concentrations in the agrochemical and seed industry: evolution of "The Big Six" (1) towards "The Big Four" (2) (total sales in seeds and pesticides in 2016 in billion USD).

\subsection{A Very Brief View of the Technological Evolution of the Seed Sector}

In addition to the economic drivers mentioned above, the consolidation in the seed industry appears also to be linked to technological changes in plant breeding, which have contributed to these trends. A very brief summary of its evolution shows the importance of these changes in the past few decades. "The domestication of crop plants began approximately 10,000 years ago by selecting for increased seeds per inflorescence, increased seedling vigor, reduced seed dormancy and dispersal/shatter, and altered plant architecture such as compact/dwarf growth and reduced branching/tillering" [36]. Until the late 19th century and the first part of the 20th century, most farmers saved seeds from their harvests and employed mass selection thereof to choose seeds for the next season. Until the end of the 19th century, this selective technique was the dominant way to breed new varieties; however, some breeders progressively introduced some improvements. At the beginning of the 20th century, the rediscovery of Mendel's laws of heredity turned plant breeding "from an art into science" [37]. Small private businesses of agricultural origin used more efficient selection methods based on the value of progeny, rather than only on the phenotype of plants. Therefore, in developed countries during the 20th century, farmers progressively bought more and more commercial seeds, supplied at that time by small enterprises.

Thus, for more than a century, and particularly after World War II, many new plant breeding techniques have been implemented as a result of scientific advances, the diffusion of hybrid seeds for certain crops-notably corn-and seed regulations. Hence, the proportion of commercial seeds has increased. However, public research has also played a considerable role in this upstream research [25]. Thus, until the 1970s, the level of concentration in the seed sector remained rather low.

The progressive implementation of these plant breeding techniques has enabled more targeted and efficient breeding, and the broadening of genetic resources, which allow plant breeders to overcome the 
limitations of conventional breeding, such as the fact that some desired traits that are missing in a given species cannot be introduced in new varieties, and the length of time that it takes to develop a new variety. Throughout the 20th century, plant breeding techniques involved many novel aspects: cross breeding, hybrid breeding, mutation breeding, cell culture, and, more recently, gene transfer, marker assisted breeding, genomic selection, etc. All these applications of scientific advances, combined with other changes in crop practices, have allowed huge improvements in yields. For example, for centuries, a wheat grain gave only, on average, three grains at harvest, of which one should be saved for the next campaign; for the period 1998-2017 it gave approximately 50 grains in France. Wheat yields in France rose at a very low pace from 1900 to 1950 and were $1.4 \mathrm{t} /$ hectare on average in that period. After 1950, they increased dramatically, by more than five times to $7.2 \mathrm{t} /$ ha for the period 1998-2017. In the USA, the average corn yield was multiplied by 5.7 , growing from $1.6 \mathrm{t} / \mathrm{ha}$ in 1866-1935 to $9.2 \mathrm{t} / \mathrm{ha}$ in 1996-2016. However, these improvements in yield are not applicable to all countries and crops. In addition to improvements in yield, numerous other traits have been introduced in varieties, such as resistance to some diseases, quality traits, and better adaptation to some food processing.

\subsection{Impact of the Technological Evolution of the Seed Industry in the Last 25 Years}

The technological evolution of the seed sector, particularly genetic engineering, has frequently led to public distrust of the seed industry. Thus, this section points out some aspects of the GMO controversy that have led to a negative view of the seed industry in the media and in a large part of the population. This negative view plays a major role in opinions of consolidation and in the regulation of ongoing innovations in the seed sector.

In the last few decades, in addition to conventional breeding, many various tools from modern biotechnology have been used: hybridization, micro-propagation, mutagenesis, protoplast fusion, and doubled-haploid production-which produces a plant resulting from chromosome doubling in a haploid cell, so that all chromosomes are present as two identical copies-as well as transgenesis and genomic selection. The first field trials of GM plants date back to 1986-1987, and their first large-scale cultivation to 1995-1996. GMOs have had a huge impact, particularly because of the intense polemics linked to genetic engineering. However, other techniques derived from biotechnology have also been used without causing the same intense controversy. Transgenic crops have caused and continue to cause acute polemic. This is due to many factors, including:

(1) Opposing assessments and analyses of the risks linked to gene transfer, as well as of the real effects of the development of GM crops in certain countries. Most scientific studies and reports assess GM crops as either positive or neutral, but with varied consequences depending on their context. However, it is essential to distinguish between the impact of GMOs and the impact of other concomitant agro-economic and technical changes, a task that is not realized in some papers. At the same time, most environmental or consumer NGOs and the media, followed by a large part of the public in a number of countries, see primarily negative consequences. These negative perceptions are predominant in some European countries, while they are much lower in North America and in some other countries [38]. The Manichean views of the involved actors have led to a war of positions between the two sides, particularly in some countries such as those in the EU. Hence, regulatory processes are blocked because of opposition between those who see mainly benefits and advantages in biotech and GMOs, and others who see mainly drawbacks and failures.

(2) Distrust among many people, with a mistrust of gene transfer from one species to another, from one kingdom to another, and a fear of unintended effects of this transfer, whether it be at the level of the genome, the plant, its composition, or in-field cultivation and its impact.

(3) The nature of the first GMOs marketed on a large scale- - tolerance to a herbicide- - has been deemed unattractive by the majority of non-farmers and non-breeders, and contrary to the first promises put forward.

(4) Many elements of an agro-economic, sociological, and ethical nature also come into play. 
(5) Finally, the debate has been transformed into an immense controversy between those in favor of the use of transgenesis in agriculture, and those who do not see any interest in it, but only risks. The controversy goes far beyond the technical aspects involved, and has turned into a war of opposition between two visions of agriculture, and two opposite worldviews, namely, the advocates of a high-tech agriculture and those advocating a more natural and more peasant agriculture. In addition, the controversy has been fueled by the fact that a number of organizations opposed to GMOs may have used the fight against GMOs as an effective means of recognition, legitimation, self-promotion, and gaining audience for their groups and activities. For their part, companies and people involved in GM crops are sure of the validity and interest of biotech applications in plant breeding, but are suspected by those opposed to hold biased views and vested interests. Hence, the divorce between these opposed views is total, and no consensus or compromise seems reachable.

Thus, this technological evolution in plant breeding, particularly GM crops, has led and is still leading to important fallouts such as:

- much controversy on the impact on food safety, food security, and the environment;

- $\quad$ strong debates regarding the authorization of GMOs for their cultivation and importation;

- poor image of the seed industry in the minds of the general public: indeed, this sector has often been strongly criticized and pictured by many activists or media as predatory, as well as imposing techniques and GM food against the will of numerous consumers; and

- effects on farmers, which depend on the type of GM trait, crop, and economic aspects, as explained in a previous paper [31]. "For farmers, the profitability of transgenic crops depends on the type of GM crop, the relative prices between GM seeds and other inputs and outputs, and on certain non-pecuniary effects (saving of time, association with other practices, etc.). GM seeds may be profitable despite their additional costs if the latter are compensated by a decrease in other input costs (such as pesticides) or by a slightly higher gross profit. Herbicide-tolerant or insect-resistant crops may allow some reduction in production costs, fewer losses, and higher yields, at least in the first few years. If certain components (fatty acids, beta-carotene, etc.) can be added to the product and lead to slightly higher production prices according to final demand, GM crops with output traits may provide a slightly greater gross value. Yet the durability of these added characteristics" must be particularly considered. "The profitability of GM crops for farmers must not be assessed only by their direct effects within a short time-period. Follow-up study is essential" [31].

The combination of the use of new techniques in plant breeding and of corporate consolidation trends has had a considerable impact in the past three decades. If the concentration level in the seed industry has increased during that period, this is linked to business strategies, to greater investments in $R \& D$ required by the new techniques, and to the increasing costs to put a new variety on the market, but mainly to the general economic and financial evolution. Indeed, the governance of the seed sector depends not only on this sector alone, but also and above all on the general governance of economic, social, and environmental issues. For example, a study by the McKinsey Global Institute [39] showed that, in the past few years, "pressure to deliver strong short-term results has increased" and "companies are using excessively short time horizons in their strategic planning". However, "companies we classify as "long term" outperform their shorter-term peers on a range of key economic and financial metrics" [39]. Today a new trend of consolidation, as well as a wave of novel plant breeding techniques such as gene editing, are underway. What will be their impact?

\section{Potential Impact of Ongoing Corporate Consolidation in the Seed Industry}

Analyzing the potential impact of corporate consolidation is rather difficult, because numerous other factors can interfere. Thus, some aspects considered as the result of consolidation may be influenced by several other interacting factors. Indeed, beside concentration trends, other major changes are underway, and play a role in the agri-food chain in the second half of the 2010s. 


\subsection{Important Changes Are Underway in the Agri-Food Chain in the Second Half of the 2010s}

In addition to advances in life sciences and biotechnology, and in applications thereof, the agri-food chain is also affected by significant economic trends, notably growing financialization. Besides major technological, agroeconomic, socioeconomic, and regulatory changes influence its stakeholders. Several new trends are indeed underway in all sectors of the agri-food chain, such as:

-A frequent advocacy for a transition towards more sustainable ways of farming, feeding, producing, and living. However, there is considerable divergence among the various actors regarding concrete directions to take in this search for better sustainability. For example, ag-input industries put forward and underline the necessity to produce more due to population growth and nutrition transition in less developed and emergent countries. In addition, they highlight the benefits of new plant breeding techniques (NPBT), which can favor environmentally-friendly production and increase yields, and thus reduce the need for additional cropland, hence preserving biodiversity and the environment. At the same time, many put forth the benefits of more grassroots and small-scale farming practices and approaches, which include the use of heirloom varieties, landraces, and farmers' seed systems, and the rejection of GMOs and NPBT. In a broad manner, the interests of the transition to agroecology are put forward by numerous organizations.

- An increase in the distrust of pesticide use, notably in Western countries, and many debates about the consequences of pesticides on the environment, biodiversity, ecosystem services, and human health. Therefore, regulatory processes for pesticides and GMOs are tightening [40], and are subject to polemics in a number of countries. For example, in the past few years, glyphosate, which is the most widely used pesticide and furthermore is associated with more than $80 \%$ of GM crops, has been at the heart of a controversy about its carcinogenic risks [41,42].

- Hence, new trends are appearing and spreading in the agricultural input sector and the agri-food chain: for example, the development of organic farming, biocontrol, and biologicals (biopesticides, biostimulants, etc.), as well as many other inputs, methods, and final products that are considered and marketed as "natural". Many crop protection companies are now investing in biologicals, which have been credited with high growth rates [43,44].

- The development of digital agriculture, new information technologies with recording of crop practices and parameters, the taking into account of soil heterogeneities, the precision use of pesticides, localized treatments, modeling, and monitoring of the spreading of disease, as well as harvest forecasts. Some seed companies, especially Monsanto, have been and are investing in this domain.

\subsection{Potential Impact of the Current Concentration Wave 2015-2016 of the Seed Industry}

The consolidation of the seed industry can have numerous spillovers and fallouts in various domains. This paper cannot analyze all of them due to length constraints, and also because a few scientific articles have already tackled certain issues, notably in the North American case $[5,6,8,10,11,45]$. This study mainly focuses on the major issues of concern, that is, the interactions between consolidation and concomitant new techniques, as well as on some risks of the biggest seed companies growing too powerful. One major impact of consolidation and the GMO controversy is an increasing distrust of the seed industry, particularly its biggest companies, which has many consequences: suspicion towards new plant breeding techniques, disagreements and disputes regarding their regulation, high divide, and conflicts between the different stakeholders and countries. Thus, this section deals with opinions and views about seed industry consolidation, considering its important consequences. Indeed, public confidence plays a great role in the economy, particularly for agricultural and food companies and products.

\subsubsection{Analyses of the Level of Concentration in the Seed Industry}

The level of concentration has strongly increased in the seed industry over the last few decades, and is increasing even more rapidly with ongoing mergers and acquisitions (Figure 7). Approximately 
the top four companies represented $8 \%$ of the total commercial market in $1985,12 \%$ in 1996, and $51 \%$ in 2016, when the 2015-2016 mergers and acquisitions are taken into account, but without considering the divestments of some products required by antitrust authorities. In this last assessment, the value of the global commercial seed market was estimated at approximately 48.5 billion USD in 2015, according to the appraisals of the International Seed Federation and some other specialists. This value is higher than the value (37 billion USD) used in several other estimates, which only considers the main global crops (see Section 2.1). Therefore, the level of concentration assessed in this paper is high, but it is lower than other estimates based on a smaller value of total seed sales. In the seed industry, the first four groups have very large revenues compared to the other seed companies, since they sell seeds, pesticides, and mainly other chemicals (pharmaceuticals, general chemicals) (Figure 10).

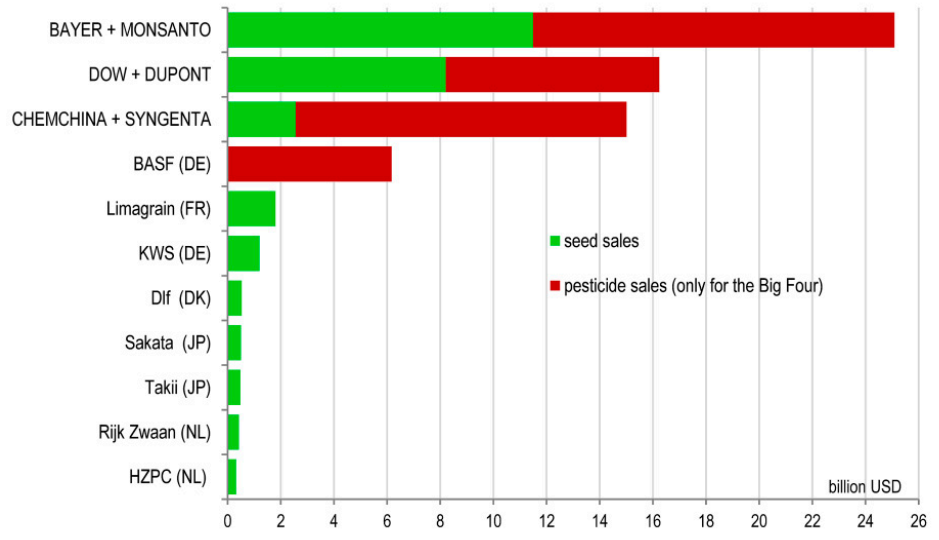

Figure 10. The leading 12 companies in the seed industry after the 2015-2016 consolidation wave (sales in billion USD). Note: Neither the divestments of some products required by antitrust authorities nor the sales of other chemicals by "The Big Four" group are taken into account.

In addition to this general view, because of the heterogeneity of the seed sector, the level of concentration is often assessed by each regulatory authority for some crops in specific markets of a given country: for example, for the US corn seed, soybean seed, and cotton seed markets [5,45].

Numerous concerns have been expressed about this ongoing corporate consolidation in the media, in scientific and newspaper articles and analyses, as well as in parliamentary hearings and debates, open letters, and calls for action. What is at stake? Two main sectors are primarily affected by this consolidation: (i) the farm sector, because of possible impacts on seed prices, seed choice, and seed diversity of species and variety; and (ii) the other seed companies, because of potential impacts on market competition, license agreements, and market power, as well as on the domain of the creation of new varieties derived from previous ones involving patents. In addition, the non-commercial seed sector, i.e., the farmers' seed systems and the public sector, may also be affected. These effects on the seed and farm sectors could bring about numerous potential fallouts throughout the whole agri-food chain, notably regarding the rate of innovation and diversity in plant breeding, the ownership of genetic resources, the environmental impacts of crops, food quality, and finally, the adequacy and sufficiency of food production and food security. In addition, consolidation can affect employment in the agricultural input sector in some regions. All these aspects explain the high number of rather negative comments regarding this ongoing consolidation trend. For example, a survey carried out in the US in June 2017 shows that 57\% of Americans "strongly oppose the merger of Monsanto and Bayer", $22 \%$ "somewhat oppose the merger", $8 \%$ "somewhat support the merger", and $10 \%$ "strongly support the merger". However, the way the question was formulated highlighted the negative consequences of the "merger" [46]. In addition, $69 \%$ of Americans expressed "very serious concerns" and $21 \%$ "somewhat serious concerns" about the consequences of this "merger." In the list of possible impacts presented, the greatest concerns were (in decreasing order): (i) "increased chemical contamination of farmland"; 
(ii) "increased chemical contamination of food"; (iii) "more expensive food products"; (iv) "lower quality food products"; and (v) "harm to independent farmers and farming communities".

However, some other actors put forth a completely different analysis of the impact of consolidation. Views on this issue vary throughout the entire industry [47]. According to one perspective, corporate consolidation increases the capacity of these large groups to develop seeds and other indispensable tools to face the agricultural and food challenges of the 21st century. Indeed, mergers and acquisitions bring together companies with complementary assets or investments, a fact that allows for more efficient organization and synergy, particularly as regards $R \& D$ and innovation. The latter are beneficial to society, most notably to consumers [12]. In addition, given that new waves of innovation are emerging, particularly regarding gene editing, digital farming, and biologicals, consolidation appears useful to better take advantage of these innovations and to implement them. For example, Monsanto's Chief Technology Officer testified before the US Congress, "We are witnessing a new era in agriculture as a result of advances in biology and data science. Silicon Valley is digitizing farming around the world. And breakthroughs like gene editing are opening up a whole new world of possibilities in plant biology. These advances are urgently needed to address major challenges facing society, as we must (i) feed 10 billion people by 2050, (ii) mitigate the impact of climate change, (iii) improve sustainability to produce more with less, and (iv) help increase the efficiency and productivity of farmers. Fortunately, the pace of innovation is accelerating, and new tools and applications are creating a healthy disruption in agriculture" [48]. In the presentation of their 2015-2016 mergers and acquisitions, all involved companies underlined how their assets and activities were complementary, and how consolidation would lead to better efficiency and to an enhanced capacity for innovation, which in turn would benefit all stakeholders. For example, in January 2017, after having met with the new US president, Bayer and Monsanto released a joint statement saying, "The driving force behind the Bayer-Monsanto combination is increasing and accelerating innovation to help growers around the world address challenges like climate change and food security. This becomes increasingly important as we all work together to feed a growing population in a sustainable way. The United States is a global leader in agriculture, and the combination of Bayer-Monsanto will underscore that role and ensure the United States retains a pre-eminent position as the anchor of the industry" [49].

\subsubsection{Impact on Seed Prices}

Many have expressed concerns about seed prices, since consolidation reduces competition, which can induce an increase in seed and agrochemical prices. This aspect is often emphasized since agricultural prices have remained low in the past few years, a fact that has brought about a decrease in input sales. In addition, many actors and organizations fear that concentration of the seed industry will have other negative consequences that could aggravate price issues [50,51]. Such issues can, for example, be aggravated by focusing plant breeding activities on seeds whose markets are the most important in value, and by directing plant breeding towards traits with quick profitability rather than towards greater long-term sustainability in agriculture, which would result in a decrease in valuable innovations. In addition, there is the risk of an increase in the dependence of SMEs on the three most important seed companies because of the numerous patents held by the latter, and because of licensing agreements $[6,8,29,52]$. Indeed, large seed companies highly dependent on financial markets and short term profits may focus mainly on major crops and some niche-markets that allow for high profits. This focus raises questions on these companies' capacity to create and put on the market new varieties for various crops suited to the vast diversity of soil, climate, agroeconomic and socioeconomic conditions, and affordability by all farmers. However, this focus on major seed markets might be an opportunity for SMEs to maintain their production of more specific seeds and landraces, and for a number of farmers to increase in part their self-sufficiency in seeds, through the development of farmers' seed systems or through participatory research, particularly in local food systems.

Certainly, the use of gene editing techniques is often presented as reducing the cost of certain genetic modifications, at least in its initial stages [53-58]. However, is this sufficient to permit some SMEs to access the implementation of new plant breeding techniques for some traits in some plants? 
This is not at all warranted. Indeed, placing a new variety on the market involves many other costs over and above the preliminary ones of obtaining a desirable genetic modification in vitro. The analysis of the overall cost to bring a new biotech trait to the market between 2008 and 2012 showed that "late discovery" represented only $10 \%$ in the total costs of a new plant biotech trait [22]. In addition, the total final cost of the variety will also depend on the regulations that will be adopted for gene editing [55,59-64]. If gene-edited (GE) plants are considered as GMOs, the cost corresponding to the regulatory aspects will be higher [65], which will favor the largest companies to the detriment of SMEs. Moreover, in certain countries such as those in the EU, new GE varieties might not be approved. In addition, food products from authorized GE crops could be rejected by consumers if there are many articles presenting them as hazardous, as the case has been for GM food products $[65,66]$. Indeed, even when some have been authorized in the EU, very few GM food products have been sold because of consumer reluctance to purchase products labeled as GMO, which is mandatory when products contain more than $0.9 \%$ of GM ingredients. Only GM feed has been commonly sold. Meanwhile, in the USA and numerous other countries, the regulation of gene editing is likely to be a case-by-case regulation based on final products rather than on the processes of production [58,67]. Hence, there is the risk of distortion of competition between countries, which in the past few decades has led to disparities between various regulations and to trade conflicts. Some suggest that high regulatory costs may favor the consolidation of companies, because these costs are easier to bear by large firms than by SMEs. In other words, if the varieties resulting from gene editing are regulated as GMOs, sector concentration may increase. This goes against the objectives of those who advocate such regulation: indeed, organizations claiming that gene-edited plants should be regulated as GMOs are usually environmentalist, peasant, or organic organizations who are also against increasing consolidation in the seed industry.

\subsubsection{Fear of Too Much Power of the Biggest Companies}

Another major concern expressed by numerous organizations and citizens is the control of the food chain by a handful of big seed companies, since seeds are at the beginning of the food chain Vandana Shiva famously declared, "We will depend on the company for every seed we plant and every field we cultivate. If it controls seeds, it controls food; it knows that, and that's its strategy. It's more powerful than bombs or weapons; it is the best way to control the people of the world" [68]. However, this concern must be tempered if one takes into account the relative economic importance, size, and power of the different stakeholders in the agri-food chain. Indeed, contrary to common belief, the main economic stakeholders are big food retailers, not seed companies. In addition to their economic size, big food retailers play a great role, since they highly influence prices along the agri-food chain. Because of strong competition amongst themselves, big food retailers exert high pressure on their suppliers to tighten prices. This considerably impacts the distribution of the added value along the agri-food chain, notably for farmers. The big retailing groups have also a major impact on the whole food chain through the globalization of the agricultural and food markets, which puts into competition all products throughout the world regardless of their conditions of production. In addition, the food retailing and food processing industries play an important role in food content, particularly for processed products that frequently contain too much added fat, salt, and sugar, which have an adverse impact on health.

Nevertheless, in addition to the downstream sector, the ag-input industry plays an important role in the agri-food chain, not only because of input prices, but also through the influence of the inputs themselves. Indeed, this industry can influence crop practices and the environmental impact of crops, as well as it can impact food quality in terms of composition, nutritional aspects, and diversity. In addition, since the largest groups involved in the seed sector also sell pesticides, many people worry about a tightening of the link between agrochemicals and seeds that runs counter to the general desire for a decreased use of pesticides. Furthermore, dependence of farmers on the upstream sector could rise with the development of digital farming. This form of agriculture entails collecting big data on crop 
practices, and the dissemination of advice and recommendations for crop practices through precision farming, decision-support tools, and digital tools based on modeling of disease, weather conditions, and soil heterogeneity. In the September 2016 presentation of its acquisition of Monsanto, Bayer put a great emphasis on "the successful integrated solutions" of "seeds $\mathcal{E}$ traits, crop protection including biologics and digital farming", and the "combined offering to fully address farmers' needs" [69].

However, for some farmer organizations, particularly in the USA, the need for input innovations, as well as their accessibility and affordability, require reducing regulations on pesticides and biotech traits, which could give greater power to the agricultural input industry. For example, the US National Corn Growers Association wrote in a letter to US Department of Justice on the acquisition of Monsanto: "Domestic regulatory hurdles for crop protection chemicals and delays in international approvals for new seed traits (...) have erected barriers to market entry, slowed down or stopped new innovations coming to market, and driven up the cost of seed and chemistry products. (...) The resulting affects are: 1) less innovation-meaning that farmers have fewer tools to combat weed and insect pressure; and 2) higher costs-as companies have higher development costs and shorter cost recovery periods" [70].

\subsubsection{Biggest Companies Are Considered Carriers of High-Tech Agriculture and a Certain} Farming Model

There are opposing views about the impact of the consolidation, as summarized in Table 2. A strong opposition appears between two visions:

(1) Some people highlight the need for high-tech agriculture and biotechnology to increase food production in the coming decades, and see the biggest companies well-placed to contribute to this goal. However, the risk of overestimating the possibilities of biotechnology or other techniques should be kept in mind.

(2) In contrast, others believe that the type of farming, developed with the use of biotechnology, is not adequate to improve agricultural production and nutritional status. Indeed, malnutrition and nutritional deficiencies are primarily due to poverty. Many malnourished people are peasants or poor farm workers, and improving their situation does not depend on the total global food production, but mainly on each peasant's or community's own production and income. Hence, other agri-food directions should be chosen.

Table 2. Opposing views about the impact of the corporate consolidation in the seed industry.

\begin{tabular}{|c|c|}
\hline Some Have Great Expectations & Others Have Strong Concerns \\
\hline $\begin{array}{l}\text { Large seed companies develop seeds and useful or } \\
\text { even indispensable tools to face the challenges of the } \\
\text { 21st century, notably thanks to their high R\&D } \\
\text { capacities. Biotech contribution will be needed for } \\
\text { crops, e.g., to give them: } \\
\text { - enhanced ability to adapt to and cope with } \\
\text { climate change; } \\
\text { - better tolerance to drought or salinity; } \\
\text { - } \quad \text { improved efficiency of nitrogen absorption; } \\
\text { - fortification of food in some healthy } \\
\quad \text { components; etc. } \\
\text { On the contrary, countries where biotech is refused } \\
\text { will lose their skills and competitiveness, and } \\
\text { increase their economic and technological } \\
\text { dependence and their imports. } \\
\text { Hence, biotech refusal in some countries could } \\
\text { increase the concentration of firms, production, and } \\
\text { exports, and thus food power in other countries and } \\
\text { by them. }\end{array}$ & $\begin{array}{l}\text { Big seed companies are seen as a danger because of } \\
\text { risk of: } \\
\text { - } \quad \text { higher seed prices; } \\
\text { - } \quad \text { decrease in the diversity of seed supply; } \\
\text { - loss of cultivated biodiversity; } \\
\text { - } \quad \text { increased intellectual property rights; } \\
\text { - } \quad \text { increased power of the largest companies on } \\
\text { others through licensing agreements; } \\
\text { - control over the seed industry and concentration } \\
\text { - } \quad \text { promotion of corporate interests with public } \\
\text { authorities and elected officials, which gives } \\
\text { large companies a strong influence. } \\
\text { Thus, control of seeds may lead to control of food, } \\
\text { which gives these companies food power. }\end{array}$ \\
\hline
\end{tabular}


In this controversy, one of the issues at stake is the type of agriculture and the farming model to adopt to best face the challenges of the coming decades, especially to sustainably increase and enhance food production. Even if these models are customized according to different situations, there remains a strong controversy between those advocating agroecology, participatory research methods, and changes in consumption patterns [71] and those advocating the use of new techniques, biotechnology, and high-tech tools or methods. In principle, agroecology and high-tech agriculture are not opposed, but complementary [72]. However, in practice these directions are often opposed, since their promoters or advocates are often in conflict. This is reinforced by the fact that big private companies upstream in the agricultural sector lack legitimacy for many citizens, particularly in some countries. This leads to fear of their products, their impact, and their role. Specifically, there are fears of: (i) the placing on the market of inputs which may be perceived as dangerous, and "poisoning" both people and land; (ii) increased dependence on technologies provided by these companies; (iii) "merchandization" of some world resources, such as genetic resources; and (iv) monopolization of certain resources by a handful of big groups or countries. These negative views play a noticeable role in some European countries, while they are less strong in North America and in some other countries. Thus, there is a clear divide regarding the direction to be taken by agriculture.

\section{Conclusions}

The recent consolidation wave in the seed industry has provoked strong reactions and concerns. It is once again drawing the public's attention to the seed sector, particularly to its major players. However, in the agri-food chain, the seed sector has a modest economic weight. The major player is the downstream food retail sector, which has a strong influence on the entire agri-food chain [73], but this is often little-known and is rarely taken into account by the general public. Another important aspect to consider in the seed sector is its heterogeneity: it is composed of a few large companies and many SMEs, and crops have very different seed values. The total value of the global commercial seed market is rather difficult to assess, and since certain amounts representing only part of the global seed market are sometimes considered as its total value, the consolidation level in the seed industry may be often overestimated due to this undervaluation. However, this level of concentration has strongly increased in the past few decades, and is increasing with ongoing mergers and acquisitions.

In the 1990s wave of consolidation, some chemical companies invested in the seed sector and in plant breeding. Indeed, it was considered as a market with a bright future because of the possibilities to develop life sciences applications that could progressively replace chemical applications. However, on the one hand, these prospects faced the rather low prices (in general) of agricultural products, a fact which compromised the possibilities of high returns, since farmers could not afford overly expensive seeds and inputs. The decrease of farmers' purchases in 2015 was an important driver of the ongoing consolidation wave. In contrast, the returns of biotechnology applications were higher in health products, where biotechnology is much more developed than in agriculture. On the other hand, activities in ag-biotech in the 1990s were faced with high opposition by numerous organizations, who feared the effects of biotechnology and found a way toward recognition, legitimation, and gaining audience in their opposition. Since they were often presented as dangerous, GM food products were poorly accepted in the EU and in some other countries. In the next few years, how will one accept the new gene-edited crops?

Many concerns have been expressed regarding the repercussions of corporate consolidation in the agri-seed sector, first and foremost regarding seed prices, hence the issue of seed affordability to many farmers. In addition, some concerns deal with: (i) the possibility and affordability of the creation of new varieties by other smaller seed companies; (ii) the diversity of seeds and the number of species worked on; and (iii) the direction of plant breeding and seed supply. However, it is important to better distinguish that which results from seed companies themselves from that which results from the financial and economic contexts in which they are embedded. Conversely, an analysis of the effects of structural change in agri-food chains needs to encompass the technological and 
sustainability dimensions, not only the economic one, as is often the case in analysis by antitrust authorities. As regards the price of a given input, it should not be considered in isolation, but rather by considering its possible contribution to better efficiency and its interactions with other inputs. For example, farmers are generally willing to purchase a more expensive input if it allows for savings (which can compensate for the higher price) or better returns down the road. This is one factor explaining the rapid adoption of GM crops in some countries, such as the USA, Brazil and Argentina. However, these possible advantages need to be analyzed over a rather long period by considering the durability of such savings or returns, as well as some unexpected consequences [74].

Concerns are also often expressed regarding the risk of too much power held by the largest seed companies due to their concentration [75]. Firstly, as seeds are at the very beginning of the agri-food chain, there are fears regarding the influence of the biggest companies on the whole chain. In addition, there are numerous concerns regarding prices, genetic resources ownership, intellectual property rights, technical recommendations to farmers, and food security. Hence, there are many concerns regarding the risk of grip on genetic resources, agricultural practices, and farming, and consequently the risk of control on food and food power. Secondly, numerous heated debates deal with certain aspects or impacts of genetic engineering and now gene-editing, as well as techno-economic trends in food and farming. However, opposed NGOs are a fierce counter-power to the feared power of the seed industry. This counter-power, however, is unevenly distributed between countries, and has resulted in very Manichean views and stubborn positions.

Another important result of concentration in the seed industry, along with its technological evolution, is the rather poor image of the whole sector, at least in some countries. This could prove to be an issue, given the importance of seeds. The seed sector deserves to be better understood in order to overcome views that are too simplistic, either positively or negatively, especially given that the commercial seed sector is very heterogeneous, and is composed not only of a few big groups, but also of many SMEs. This paper has given a general analysis of the ongoing consolidation wave. Several of its aspects and consequences need further research: not only the few big seed groups, but also the whole seed sector, notably SMEs, farmers' seed systems, farm saved seeds, and public research.

Stakeholders disagree about the impact of corporate concentration in the seed industry. For many people, it raises considerable concern, and fear of its negative consequences for food security and of the possibility of too much power held by the biggest companies. For a few others, these large seed companies are seen as very creative, and having the capacity to bring innovations critical for future agriculture, food, and the bioeconomy due to their high capacity for R\&D. These two contrasting views seem to be linked to the controversy over the direction that agriculture should take to face the challenges of the 21st century, particularly between the two options of high-tech agriculture and agroecology.

Acknowledgments: This paper is the result of a research work carried out without special funding, i.e., with the basic support provided by INRA (French National Institute for Agricultural Research), which is a public research institute and a publicly funded institution.

Conflicts of Interest: The author declares no conflict of interest.

\section{Abbreviations}

$\begin{array}{llll}\text { GE crop } & \text { Gene-Edited crop } & \text { NPBT } & \text { New Plant Breeding Techniques } \\ \text { GM crop } & \text { Genetically Modified crop } & \text { R\&D } & \text { Research and Development } \\ \text { GMO } & \text { Genetically Modified Organism } & \text { SME } & \text { Small and Medium Enterprise } \\ \text { NGO } & \text { Non-Governmental Organization } & & \end{array}$

\section{References}

1. ETC Group. Breaking Bad: Big Ag Mega-Mergers in Play. Dow + DuPont in the Pocket? Next: Demonsanto? ETC Group, Communiqué \#115. 2015. Available online: http:/ / www.etcgroup.org/sites / www.etcgroup. org/files/files/etc_breakbad_23dec15.pdf (accessed on 11 July 2017). 
2. FoEE. Marriages Made in Hell, Why Agribusiness Megamergers Must Be Stopped; Friends of the Earth Europe: Berlin, Germany, 2017; Available online: http://www.foeeurope.org/marriages-in-hell (accessed on 7 September 2017).

3. Heinrich-Böll Foundation. KONZERNATLAS Daten und Fakten über die Agrar-und Lebensmittelindustrie; Heinrich-Böll-Stiftung: Berlin, Germany, 2017; p. 52.

4. Shiva, V. Seed Freedom and Food Freedom in Times of Globalisation. Available online: http:/ / soscbaha. org/downloads/mcrl2013.pdf (accessed on 7 September 2017).

5. Bryant, H.A.; Maisashvili, J.; Outlaw, J.; Richardson, J. Effects of Proposed Mergers and Acquisitions among Biotechnology Firms on Seed Prices. Texas A\&M University, Agricultural and Food Policy Center; p. 35. Available online: http:/ / texascorn.org/wp-content/uploads/2016/09/AFPCMAStudy_092016.pdf (accessed on 7 September 2017).

6. Clapp, J. Bigger Is Not Always Better: The Drivers and Implications of the Recent Agribusiness Megamergers; University of Waterloo: Waterloo, ON, Canada, 2017.

7. Concurrences. Competition Law and Policy and the Food Value Chain. 2016. Available online: https://www.concurrences.com/en/review/issues/no-1-2016/on-topic/competition-law-andpolicy-and-the-food-value-chain (accessed on 11 July 2017).

8. Howard, P.H. Concentration and Power in the Food System: Who Controls What We Eat? Bloomsbury Publishing: London, UK, 2016; p. 207.

9. Lianos, I.; Katalevsky, D.; Ivanov, A. The Global Seed Market, Competition Law and Intellectual Property Rights: Untying the Gordian Knot; Faculty of Laws, Centre for Law, Economics and Society: London, UK, 2016; Available online: https: / / ssrn.com/abstract=2773422 (accessed on 11 July 2017).

10. Maisashvili, A.; Bryant, H.; Raulston, J.M.; Knapek, G.; Outlaw, J.; Richardson, V. Seed Prices, Proposed Mergers and Acquisitions among Biotech Firms. Choices 2016, 31, 7-11.

11. McDonald, J. Mergers and Competition in Seed and Agricultural Chemical Markets. Amber-Waves (USDA Economic Research Service); April 2016. Available online: https:/ /www.ers.usda.gov/amber-waves/2017/ april/mergers-and-competition-in-seed-and-agricultural-chemical-markets/ (accessed on 11 July 2017).

12. Manne, G.A.; Gibby, A. A Brief Assessment of the Procompetitive Effects of Organizational Restructuring in the Ag-Biotech Industry; The International Center for Law and Economics (ICLE): Portland, OR, USA, 2017; Available online: https:/ / truthonthemarket.com/2017/05/09/procompetitive-effects-of-organizationalrestructuring-in-the-ag-biotech-industry/ (accessed on 7 September 2017).

13. Hampton, J.G.; Conner, A.J.; Boelt, B.; Chastain, T.G.; Rolston, P. Climate Change: Seed Production and Options for Adaptation. Agriculture 2016, 6, 33. [CrossRef]

14. Wikipedia. Genetically Modified Food Controversies. Available online: https://en.wikipedia.org/wiki / Genetically_modified_food_controversies (accessed on 11 July 2017).

15. Falkner, R. The Troubled Birth of the "Biotech Century": Global Corporate Power and Its Limits. In Corporate Power in Global Agrifood Governance; Clapp, J., Fuchs, D., Eds.; MIT Press: Cambridge, MA, USA, 2009; pp. 225-252.

16. US Department of Agriculture. 2012 Census Full Report; US Department of Agriculture: Washington, DC, USA, 2014. Available online: https:/ / www.agcensus.usda.gov/Publications/2012/ (accessed on 11 July 2017).

17. Agreste, RICA. Rica France Tableaux Standard 2014; Agreste, Chiffres et Données-Série Agriculture $n^{\circ} 233$ mars 2016. Available online: http:/ / agreste.agriculture.gouv.fr/publications/chiffres-et-donnees/article/ rica-france-tableaux-standard-2014 (accessed on 11 July 2017).

18. Forbes. The World's Biggest Public Companies (Year 2016); Forbes: Jersey City, NJ, USA, 2017; Available online: https:/ / www.forbes.com/global2000/list/\#header:revenue_sortreverse:true (accessed on 11 July 2017).

19. International Treaty on Plant Genetic Resources for Food and Agriculture, FAO. The Launch Mechanism; Working Documents of the 6th Meeting of the Ad Hoc Open-Ended Working Group to Enhance the Functioning of the Multilateral System; FAO: Rome, Italy, 2017; Available online: http:/ www.fao.org/3/abr428e.pdf (accessed on 11 September 2017).

20. Keller, M.; Gabsi, R. The ISF (International Seed federation) Rules for Trade. In Proceedings of the Congress of AFSTA (African Seed Trade Association), Nairobi, Kenya, 3 March 2016.

21. KWS. Investor Presentation. KWS SAAT SE: Einbeck, Germany, May 2017. Available online: https:/ / www. kws.com/global/show_document.asp?id=aaaaaaaaaawnrje (accessed on 11 September 2017). 
22. McDougall, P. The Cost and Time Involved in the Discovery, Development and Authorisation of a New Plant Biotechnology Derived Trait. Consultancy Study for CropLife International: Midlothian, UK, 2011. Available online: https:/ / croplife.org/plant-biotechnology/regulatory-2/ cost-of-bringing-a-biotech-crop-to-market/ (accessed on 11 July 2017).

23. Phillips McDougall. The Cost of New Agrochemical Product Discovery, Development and Registration in 1995, 2000, 2005-8 and 2010 to 2014; A Consultancy Study for CropLife International. CropLife America and the European Crop Protection Association: Midlothian, UK, 2016; p. 41. Available online: http: / www. croplifeamerica.org/wp-content/uploads/2016/04/Phillips-McDougall-Final-Report_4.6.16.pdf (accessed on 11 September 2017).

24. Clancy, M.S.; Moschini, G. Intellectual Property Rights and the Ascent of Proprietary Innovation in Agriculture. Annu. Rev. Resour. Econ. 2016. [CrossRef]

25. Fuglie, K.O.; Clancy, M.; Heisey, P. Private Sector Research and Development. Presented at the 21st ICABR Conference "Bioeconomy in Transition: New Players and New Tools", University of California, Berkeley, CA, USA, 31 May 2017.

26. Dunwell, J.M. Mergers and Acquisitions in Global Ag-Biotech. In Biotechnology of Major Cereals; Jones, H.D., Ed.; CABI: Wallingford, UK, 2016; pp. 206-221.

27. Fernandez-Cornejo, J. The Seed Industry in US Agriculture: An Exploration of Data and Information on Crop Seed Markets, Regulation, Industry Structure, and Research and Development. Agriculture Information Bulletin 786; USDA Economic Research Service, 2004. Available online: https:/ / www.ers.usda. gov / publications / pub-details / ?pubid=42531 (accessed on 11 July 2017).

28. Fuglie, K.O.; Heisey, P.; King, J.L.; Day-Rubenstein, K.; Schimmelpfennig, D.; Wang, S.L.; Karmarkar-Deshmukh, R. Research Investments and Market Structure in the Food Processing, Agricultural Input, and Biofuel Industries Worldwide; U.S. Dept. of Agriculture, Econ. Res. Serv.: Washington, DC, USA, 2011. Available online: https:/ / www.ers.usda.gov/publications/pub-details / ?pubid=44954 (accessed on 11 July 2017).

29. Howard, P.H. Visualizing consolidation in the global seed industry: 1996-2008. Sustainability 2009, 1, 1266-1287. [CrossRef]

30. ISAAA. Global Status of Commercialized Biotech/GM Crops: 2016; ISAAA (International Service for the Acquisition of Agri-biotech Applications): Ithaca, NY, USA, 2016; p. 125.

31. Bonny, S. Taking Stock of the Genetically Modified Seed Sector Worldwide: Market, Stakeholders, and Prices. Food Secur. 2014. [CrossRef]

32. IMAA. Number and Value and Largest Mergers, Acquisitions and Alliances Transactions by Year, 1985-2017; IMAA (Institute of Mergers, Acquisitions and Alliances), Webster University: Vienna, Austria, 2017; Available online: https: / /imaa-institute.org/m-and-a-statistics-transaction-type/ (accessed on 11 July 2017).

33. Schenkelaars, P.; de Vriend, H.; Kalaitzandonakes, N.; Magnier, A.; Miller, D. Drivers of Consolidation in the Seed Industry and Its Consequences for Innovation; COGEM Report; Commission on Genetic Modification: Bilthoven, The Netherlands, 2011; 123p, Available online: http://www.gruenevernunft.de/meldung/ drivers-consolidation-seed-industry-and-its-consequences-innovation (accessed on 8 September 2017).

34. Baines, J. Food Price Inflation as Redistribution: Towards a New Analysis of Corporate Power in the World Food System. New Political Econ. 2014, 20, 79-112. [CrossRef]

35. Baumann, W. Werner Baumann (Bayer CEO) interview: "Ich zittere gar nicht". Die Zeit. 13 December 2016. Available online: http://www.zeit.de/2016/49/werner-baumann-bayer-monsanto-interview / komplettansicht (accessed on 11 July 2017).

36. Songstad, D.D.; Petolino, J.F.; Voytas, D.F.; Reichert, N.A. Genome editing of plants. Crit. Rev. Plant Sci. 2017, 36, 1-23. [CrossRef]

37. Jorasch, P. How Much Plant Breeding Innovation is Politically Intended? Eur. Seed 2017, 3, 2016. Available online: http:/ / european-seed.com/much-plant-breeding-innovation-politically-intended/ (accessed on 11 July 2017).

38. National Science Board. Science and Technology: Public Attitudes and Understanding and Appendix Tables. In Science and Engineering Indicators; National Science Foundation: Arlington, VA, USA, 2014.

39. McKinsey Global Institute. Measuring the Economic Impact of Short-Termism; McKinsey Global Institute: New York, NY, USA, 2017. 
40. Sparks, T.C.; Lorsbach, B.A. Perspectives on the agrochemical industry and agrochemical discovery. Pest Manag. Sci. 2017, 73, 672-677. [CrossRef] [PubMed]

41. Myers, J.P.; Antoniou, M.N.; Blumberg, B.; Carroll, L.; Colborn, T.; Everett, L.G.; Vandenberg, L.N.; Hansen, M.; Landrigan, P.J.; Lanphear, B.P.; et al. Concerns over use of glyphosate-based herbicides and risks associated with exposures: A consensus statement. Environ. Health 2016, 15, 19. [CrossRef] [PubMed]

42. Tarazona, J.V.; Court-Marques, D.; Tiramani, M.; Reich, H.; Pfeil, R.; Istace, F.; Crivellente, F. Glyphosate toxicity and carcinogenicity: A review of the scientific basis of the European Union assessment and its differences with IARC. Arch. Toxicol. 2017. [CrossRef] [PubMed]

43. Agrow. Biologicals 2017. An Analysis of Corporate, Product and Regulatory News in 2016/2017; Agrow, Agribusiness Intelligence, Informa UK: London, UK, 2017; p. 44. Available online: https: / /agrow.agribusinessintelligence.informa.com/- / media/agri/agrow/ag-market-reviews-pdfs / supplements/agrow_biologicals_2017_online.pdf (accessed on 11 September 2017).

44. Pelaez, V.; Mizukawa, G. Diversification strategies in the pesticide industry: From seeds to biopesticides. Ciência Rural 2017. [CrossRef]

45. Stucke, M.E.; Grunes, A.P. An Antitrust Review of a Bayer-Monsanto Merger; The Konkurrenz Group: Washington, DC, USA, 2016.

46. Public Policy Polling. National Survey Results. Available online: http://webiva-downton.s3.amazonaws. com/877/9d/8/10411/NationalPollResults.pdf (accessed on 11 July 2017).

47. Bhattacharya, H.; Innes, R. Concentration, Product Variety, Entry-for-Merger, Evidence from New Product Intro in US Food Industry. Am. J. Agric. Econ. 2016, 98, 1360-1376. [CrossRef]

48. Fraley, R. Testimony before the Senate Committee on the Judiciary Hearing on "Consolidation and Competition in the U.S. Seed and Agrochemical Industry". Monsanto, 20 September 2016. Available online: https: / www.judiciary.senate.gov/download/09-20-16-johnson-testimony (accessed on 11 July 2017).

49. Bayer; Monsanto. Joint Statement: Monsanto, Bayer CEOs Meet with New Administration. Bayer, Monsanto Press Release 17 January 2017. Available online: https:/ / www.advancingtogether.com/en/ir-media/pressreleases / (accessed on 11 July 2017).

50. Moss, D. Testimony before the Senate Committee on the Judiciary Hearing on "Consolidation and Competition in the U.S. Seed and Agrochemical Industry". Washington, DC, USA, 20 September 2016. Available online: https://www.judiciary.senate.gov/download/09-20-16-moss-testimony (accessed on 11 July 2017).

51. Johnson, R. Testimony of R Johnson before the Senate Committee on the Judiciary Hearing on "Consolidation and Competition in the U.S. Seed and Agrochemical Industry"; NFU (National Farmers Union): Washington, DC, USA, 2016. Available online: https:/ / www.judiciary.senate.gov/download/09-20-16-johnson-testimony (accessed on 11 July 2017).

52. Howard, P.H. Intellectual property and consolidation in the seed industry. Crop Sci. 2015, 55, $2489-2495$. [CrossRef]

53. Huang, S.; Weigel, D.; Beachy, R.N.; Li, J. A proposed regulatory framework for genome-edited crops. Nat. Genet. 2016, 48, 109-111. [CrossRef] [PubMed]

54. IP Pragmatics. Gene Editing Technology: Market Assessment and Intellectual Property Landscape; IP Pragmatics: London, UK, 2016; Available online: http://www.ip-pragmatics.com/downloads/pdf/ IPPragmaticsGeneEditingWhitePaper_June2016.pdf (accessed on 11 July 2017).

55. Wolt, J.D.; Wang, K.; Yang, B. The Regulatory Status of Genome-edited Crops. Plant Biotechnol. J. 2016, 14, 510-518. [CrossRef] [PubMed]

56. European Commission (EC); DG for Research and Innovation. New Techniques in Agricultural Biotechnology; EC, Directorate-General for Research and Innovation: Brussels, Belgium, 2017; 152p, Available online: https:/ / ec.europa.eu/research/sam/pdf/topics/explanatory_note_new_techniques_agricultural_ biotechnology.pdf (accessed on 11 July 2017).

57. Scheben, A.; Edwards, D. Genome editors take on crops. Science 2017, 355, 1122-1123. [CrossRef] [PubMed]

58. NAS (US National Academies of Sciences, Engineering, and Medicine). Preparing for Future Products of Biotechnology; The National Academies Press: Washington, DC, USA, 2017.

59. Kalaitzandonakes, N.; Alston, J.M.; Bradford, K.J. Compliance costs for regulatory approval of new biotech crops. Nat. Biotechnol. 2007, 25, 509-511. [CrossRef] [PubMed] 
60. Lusser, M.; Parisi, C.; Plan, D.; Rodriguez-Cerezo, E. Deployment of new biotechnologies in plant breeding. Nat. Biotechnol. 2012, 30, 231-239. [CrossRef] [PubMed]

61. Voytas, D.F.; Gao, C. Precision genome engineering and agriculture: opportunities and regulatory challenges. PLoS Biol. 2014, 12, 1001877. [CrossRef] [PubMed]

62. Prado, J.R.; Segers, G.; Voelker, T.; Carson, D.; Dobert, R.; Phillips, J.; Reynolds, T. Genetically engineered crops: From idea to product. Annu. Rev. Plant Biol. 2014. [CrossRef] [PubMed]

63. Jones, H.D. Regulatory uncertainty over genome editing. Nat. Plants 2015. [CrossRef] [PubMed]

64. Strauss, S.H.; Sax, J.K. Ending event-based regulation of GMO crops. Nat. Biotechnol. 2016, 34, $474-477$. [CrossRef] [PubMed]

65. Hartung, F.; Schiemann, J. Precise plant breeding using new genome editing techniques: opportunities, safety and regulation in the EU. Plant J. 2014, 78, 742-752. [CrossRef] [PubMed]

66. Lucht, J.M. Public acceptance of plant biotechnology and GM crops. Viruses 2015, 7, 4254-4281. [CrossRef] [PubMed]

67. European Parliamentary Research Service (EPRS). New Plant-Breeding Techniques: Applicability of GM Rules; EPRS Briefing: Brussels, Belgium, 2016; p. 8. Available online: http:/ /www.europarl.europa.eu/thinktank/ en / document.html?reference=EPRS_BRI(2016)582018 (accessed on 8 September 2017).

68. Robin, M.M. The World According to Monsanto: Pollution, Corruption, and the Control of the World's Food Supply; The New Press: New York, NY, USA, 2008; p. 384.

69. Bayer. Advancing together. Bayer to Acquire Monsanto. Creating a Global Leader in Agriculture. Available online: http:/ / www.press.bayer.com/baynews / baynews.nsf/id/Bayer-Offers-to-Acquire-Monsanto-toCreate-a-Global-Leader-in-Agriculture (accessed on 7 September 2017).

70. National Corn Growers Association (NCGA). Letter to Department of Justice on Bayer-Monsanto-Acquisition. NCGA, 2 May 2017. Available online: http:/ / www.ncga.com/topics/mergers (accessed on 11 July 2017).

71. Méndez, V.E.; Caswell, M.; Gliessman, S.R.; Cohen, R. Integrating Agroecology and Participatory Action Research (PAR): Lessons from Central America. Sustainability 2017, 9, 705. [CrossRef]

72. Bonny, S. High-tech agriculture or agroecology for tomorrow's agriculture? Harv. Coll. Rev. Environ. Soc. 2017, 28-34. Available online: https://issuu.com/harvarduniversityreviewofenvironmen/docs/hcres_2017 (accessed on 11 July 2017).

73. De Schutter, O. The political economy of food systems reform. Eur. Rev. Agric. Econ. 2017, 44, 705-731. [CrossRef]

74. Bonny, S. Genetically Modified Herbicide-Tolerant Crops, Weeds, and Herbicides: Overview and impact. Environ. Manag. 2016, 57, 31-48. [CrossRef] [PubMed]

75. Khan, L.; Vaheesan, S. Market Power and Inequality: The Antitrust Counterrevolution and Its Discontents. Harv. Law Policy Rev. 2017, 11, 235-294. 